OPEN ACCESS

Edited by:

Ben P. Harvey,

University of Tsukuba, Japan

Reviewed by:

Christian Pansch,

Åbo Akademi University, Finland

Naoko Isomura,

Okinawa College, Japan

${ }^{*}$ Correspondence:

Haruko Kurihara

harukoku@sci.u-ryukyu.ac.jp;

harukoku@e-mail.jp

Specialty section:

This article was submitted to Global Change and the Future Ocean,

a section of the journal

Frontiers in Marine Science

Received: 08 July 2020 Accepted: 15 October 2020 Published: 27 November 2020

Citation:

Kurihara H, Suhara Y, Mimura I and Golbuu Y (2020) Potential

Acclimatization and Adaptive Responses of Adult and Trans-Generation Coral Larvae From a Naturally Acidified Habitat.

Front. Mar. Sci. 7:581160. doi: 10.3389/fmars.2020.581160

\section{Potential Acclimatization and Adaptive Responses of Adult and Trans-Generation Coral Larvae From a Naturally Acidified Habitat}

\author{
Haruko Kurihara $^{1 *}$, Yuri Suhara', Izumi Mimura' ${ }^{1}$ and Yimnang Golbuu' \\ ${ }^{1}$ Department of Science, University of the Ryukyus, Nishihara, Japan, ${ }^{2}$ Palau International Coral Reef Center, Koror, Palau
}

Coral reefs are one of the most susceptible ecosystems to ocean acidification $(O A)$ caused by increasing atmospheric carbon dioxide $\left(\mathrm{CO}_{2}\right)$. $\mathrm{OA}$ is suspected to impact the calcification rate of corals as well as multiple early life stages including larval and settlement stages. Meanwhile, there is now a strong interest in evaluating if organisms have the potential for acclimatization or adaptation to OA. Here, by taking advantage of a naturally acidified site in Nikko Bay, Palau where corals are presumably exposed to high $\mathrm{CO}_{2}$ conditions for their entire life history, we tested if adult and the next-generation larvae of the brooder coral Pocillopora acuta originating from the high- $\mathrm{CO}_{2}$ site are more tolerant to high $\mathrm{CO}_{2}$ conditions compared to the individuals from a control site. Larvae released from adults collected from the high- $\mathrm{CO}_{2}$ site within the bay and a control site outside the bay were reciprocally cultivated under experimental control or high- $\mathrm{CO}_{2}$ seawater conditions to evaluate their physiology. Additionally, reciprocal transplantation of adult $P$. acuta corals were conducted between the high- $\mathrm{CO}_{2}$ and control sites in the field. The larvae originating from the control site showed lower Chlorophyll-a content and lipid percentages when reared under high- $\mathrm{CO}_{2}$ compared to control seawater conditions, while larvae originating from the high- $\mathrm{CO}_{2}$ site did not. Additionally, all 10 individuals of adult $P$. acuta from control site died when transplanted within the bay, while all $P$. acuta corals within the bay survived at both control and high- $\mathrm{CO}_{2}$ site. Furthermore, $P$. acuta within the bay showed higher calcification and net photosynthesis rates when exposed to the condition they originated from. These results are one of the first results that indicate the possibility that the long-living corals could enable to show local adaptation to different environmental conditions including high seawater $\mathrm{pCO}_{2}$.

Keywords: coral, high- $\mathrm{CO}_{2}$, local adaptation, trans-generation acclimatization, naturally acidified site

\section{INTRODUCTION}

Coral reefs are highly susceptible to ocean acidification (OA) which is caused by increasing concentrations of atmospheric carbon dioxide $\left(\mathrm{CO}_{2}\right.$; Hoegh-Guldberg et al., 2007). Seawater $\mathrm{pH}$ is expected to decrease by about $0.2-0.4$ units compared to present levels of 8.1 by the end of this century according to the RCP scenarios (IPCC, 2014). Because the seawater calcium carbonate saturation $(\Omega)$ decreases with OA, the calcification rate of most calcifiers including 
corals, is expected to decrease in the future ocean (Kleypas et al., 2005; Chan and Connolly, 2013). Additionally, OA has been reported to impact multiple life stages of corals, including fertilization (Albright and Mason, 2013), larval (Nakamura et al., 2011; Putnam et al., 2013), and settlement (Doropoulos et al., 2012), suggesting strong impacts of OA on corals and coral reef ecosystems.

Meanwhile, more recent studies reported that the responses of marine calcifiers to OA could vary among species and even among populations or individuals within a species (Kroeker et al., 2010; McCulloch et al., 2012). These findings stimulate ideas about acclimatization or adaptation potential of organisms to OA (Pandolfi et al., 2011; Kelly and Hofmann, 2012; Sunday et al., 2014; Vargas et al., 2017). Indeed, some experimental studies demonstrated potential existence of genetic variations (e.g., sea urchins: Sunday et al., 2011) or phenotypic plasticity (e.g., corals: Putnam et al., 2016) to high $p \mathrm{CO}_{2}$ environment. Additionally, acclimatization by "trans-generational plasticity" such that offspring of parents exposed to OA can show higher tolerance to OA have also been indicated (Munday, 2014; Lamare et al., 2016; Thomsen et al., 2017). When the parents of anemone fish were cultured under high $p \mathrm{CO}_{2}$, it was found that the effects of high $p \mathrm{CO}_{2}$ were absent or reversed in terms of the survival or size of their juveniles (Miller et al., 2012). Putnam and Gates (2015) studied the trans-generational acclimatization potential of the coral Pocillopora damicornis to high $p \mathrm{CO}_{2}$ and temperature conditions, and found that the exposure of coral parents to those conditions may alleviate stress in next-generation larval stages. However, one of the limitations of these studies are that the exposure time of parents to the $\mathrm{OA}$ condition is restricted to a limited period of time or life stages (e.g., 1.5 months for the coral $P$. damicornis). Although evolution experiments studying the processes of adaptation to high $p \mathrm{CO}_{2}$ using short generation organisms such as phytoplankton are now available (Lohbeck et al., 2012), we still lack for understanding multigeneration effects of OA on particularly long-living organisms such as corals (Torda et al., 2017). In this context, organisms living in naturally acidified sites such as on $\mathrm{CO}_{2}$ vents (Hall-Spencer et al., 2008; Fabricius et al., 2011; Inoue et al., 2013) and sheltered lagoon (Shamberger et al., 2014; Golbuu et al., 2016) can be an ideal model to test adaptation potential and trans-generation responses to high $p \mathrm{CO}_{2}$ (Calosi et al., 2013; Harvey et al., 2016; Welch and Munday, 2017).

Here we focused on the coral Pocillopora acuta living in Nikko Bay, Palau, where the seawater shows naturally low $\mathrm{pH}$ and high $p \mathrm{CO}_{2}$ conditions with the aim of testing for the first time if adult and the next-generation larval stages of corals exposed to low $\mathrm{pH}$ for their entire life cycle show potential adaptation response to the OA. Seawater pH within Nikko Bay is 0.2-0.3 lower than that outside the bay, which is suggested to be caused by the net decomposition and net calcification by the organisms within the bay (Shamberger et al., 2014; Golbuu et al., 2016; Kurihara et al., unpublished data). The seawater residence time within the bay is also known to exceed 70 days (Golbuu et al., 2016), suggesting that the organisms within the bay may be genetically isolated from outside the bay (e.g., vermetid Cerasignum maximum: Soliman et al., 2019). This is likely so for P. acuta a brooder species, which releases larvae that mostly settled within 1-2 days (Kopp et al., 2016); they are thus suggested to have less dispersion capacity compared to spawning corals (Isomura and Nishihira, 2001; Nishikawa et al., 2003). This species has recently been identified as a cryptic species of coral P. damicornis complex (Schmidt-Roach et al., 2013).

In this study we tested if the adults and the larvae of $P$. acuta originating from the high- $\mathrm{CO}_{2}$ site within Nikko Bay are more tolerant to high $p \mathrm{CO}_{2}$ conditions compared to the adult and larvae from the control site outside the bay, respectively. To examine this hypothesis, we first conducted a reciprocal cultivation of larvae released from high- $\mathrm{CO}_{2}$ and control site corals $P$. acuta under experimental control or high $\mathrm{pCO}_{2}$ seawater conditions and evaluated their physiology including photosynthesis, respiration, zooxanthella density, chlorophyll- $a$ (Chl-a) concentration, and lipid content. Additionally, reciprocal transplantation of adult colonies was conducted between the high- $\mathrm{CO}_{2}$ and control site in the field, to evaluate their fitness by examining survival rate and physiology including calcification, photosynthesis, and respiration rate.

\section{MATERIALS AND METHODS}

\section{Coral Collection for Larval Experiment}

Five different colonies of the coral $P$. acuta were collected from each of two sites (high- $\mathrm{CO}_{2}$ and control site, both 4$5 \mathrm{~m}$ depth) in Palau on March 15, 2018 that have different seawater $p \mathrm{CO}_{2}$ concentrations. The high- $\mathrm{CO}_{2}$ site was within Nikko Bay $\left(7^{\circ} 19^{\prime} 13.2^{\prime \prime} \mathrm{N}, 134^{\circ} 30^{\prime} 00.6^{\prime \prime} \mathrm{E}\right)$ where seawater $p \mathrm{CO}_{2}$ is naturally high $(1,123 \mu \mathrm{atm} / \mathrm{pH} 7.77)$ and represents the value expected by the end of this century (RCP 8.5 IPCC). The control site was outside of Nikko Bay $\left(7^{\circ} 18^{\prime} 15.3^{\prime \prime} \mathrm{N}, 134^{\circ} 30^{\prime} 01.4^{\prime \prime} \mathrm{E}\right)$ where seawater $p \mathrm{CO}_{2}$ shows normal concentrations (mean $\pm \mathrm{SD}$ : $416 \pm 73 \mu \mathrm{atm} / \mathrm{pH} 8.15 \pm 0.06, n=3$, Table 1) equivalent to present conditions (Table 1). The high $\mathrm{pCO}_{2}$ and low $\mathrm{pH}$ condition within the bay is suggested to be caused mainly by high dissolved inorganic carbon (DIC) and low alkalinity resulting from net decomposition and net calcification by the organisms within the bay which has a high seawater residence time (Shamberger et al., 2014; Golbuu et al., 2016; Kurihara et al., unpublished data). In addition to seawater $p \mathrm{CO}_{2}$, the average seawater temperature was also slightly higher (about $1.0^{\circ} \mathrm{C}$ ) and the light intensity significantly lower within Nikko Bay compared to the control site (Supplementary Figure 1). The bottom seawater $\mathrm{pH}$ and salinity at both sites were measured by casts of a multi-parameter water quality sensor (AAQRINKO, JFE Advantech Co., Ltd., Japan). Bottom seawater samples were also collected three times using a Van Don water sampler for the measurement of total alkalinity (TA) and nutrient concentrations. Seawater TA was measured using an auto burette titrator (ATT-05, KIMOTO, Japan) with precision evaluated by analyzing certified reference materials (CRMs) supplied by the A. Dickson laboratory, Scripps Institution of Oceanography. Seawater for nutrient concentration analysis (4 replicates per sampling) was filtered through pre-combusted filters and frozen until measurement using an AACS II (BRAN+LUEBBE, 


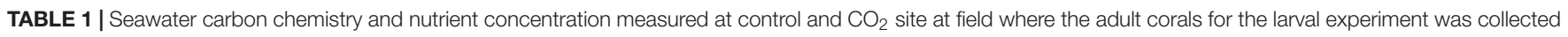
and seawater carbon chemistry during the larval experiments in laboratory.

\begin{tabular}{|c|c|c|c|c|c|c|}
\hline & & Temperature & Salinity & pH (NBS scale) & $\mathrm{pCO}_{2}$ & $\mathrm{TA}\left(\mu \mathrm{mol} \mathrm{Kg}^{-1}\right)$ \\
\hline \multirow[t]{2}{*}{ Field } & Control site & $29.3 \pm 0.3$ & $33.6 \pm 0.03$ & $8.15 \pm 0.06$ & $416 \pm 73$ & $2115 \pm 4.5$ \\
\hline & CO2 site & $30.1 \pm 0.4$ & $33.1 \pm 0.1$ & $7.77 \pm 0.02$ & $1123 \pm 83$ & $2069 \pm 14$ \\
\hline \multirow[t]{3}{*}{ Experiment } & Control & $29.2 \pm 0.7$ & $33.7 \pm 0.12$ & $8.09 \pm 0.12$ & $504 \pm 164$ & $2106 \pm 6.5$ \\
\hline & $\mathrm{CO} 2$ & $29.3 \pm 0.7$ & $33.6 \pm 0.16$ & $7.74 \pm 0.15$ & $1301 \pm 465$ & $2110 \pm 7$ \\
\hline & & $\mathrm{NO}_{3}{ }^{2-}+\mathrm{NO}_{2}-$ & $\mathrm{NH}_{4}{ }^{3+}$ & $\mathrm{PO}_{4}{ }^{3-}$ & Light intensity & \\
\hline \multirow[t]{2}{*}{ Field } & Control site & $0.1 \pm 0.05$ & $0.5 \pm 0.3$ & $0.03 \pm 0.01$ & $336 \pm 341$ & \\
\hline & CO2 site & $0.5 \pm 0.2$ & $0.3 \pm 0.2$ & $0.07 \pm 0.02$ & $71 \pm 95$ & \\
\hline
\end{tabular}

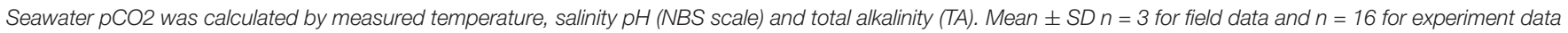
for carbon chemistry. $n=12$ for nutrient analysis.

Table 1). Seawater temperature and light intensity were recorded using temperature data logger (U22-001, HOBO V2, Onset Corp., United States) and light quantum (DEFI-L, JFE Advantech Co., Ltd., Japan) data loggers installed at each site for around 2 weeks (Supplementary Figure 1).

\section{Experimental Set-Up for Larval Experiment}

After collection, all corals were immediately brought to the Palau International Coral Reef Center (PICRC) and each 5 colonies was placed individually within 10 aquaria $(36 \times 22 \times 26 \mathrm{~cm})$ in which seawater $p \mathrm{CO}_{2}$ was maintained at the comparable condition as where the corals were collected (control condition: $504 \pm 164 \mu \mathrm{atm} / \mathrm{pH} 8.09 \pm 012$; high $-\mathrm{CO}_{2}$ condition: $1301 \pm 465 \mu \mathrm{atm} / \mathrm{pH} 7.74 \pm 0.15, n=16$ ) (Table 1). Seawater $p \mathrm{CO}_{2}$ was controlled by bubbling running seawater pumped from the ocean in front of PICRC with air mixed with either $\mathrm{CO}_{2}$ gas or air only. Flow rates of $\mathrm{CO}_{2}$ gas and air were controlled by mass flow controllers (SEC-E40, HoribaSTEC, Japan). Seawater $\mathrm{pH}$ (NBS scale) and salinity were measured, respectively, using a $\mathrm{pH}$ sensor (SenTix 940-3) and salinity sensor (TetraCon 925) connected to a multi-parameter portable meter (WTW Multi 3420, Germany). Seawater was sampled from aquaria for TA measurement and seawater $p \mathrm{CO}_{2}$ and DIC was calculated using the CO2sys program of Lewis and Wallace (1998).

\section{Coral Larvae}

Two days after coral sampling, corals started to release larvae, which peaked on March 20 and 21 and lasted for about 1 week. Coral larvae were collected each day in a plastic container with a plankton mesh side installed at side of each aquaria every night (19:00) such that seawater exiting the aquaria flowed into the containers. Larval collection last for 6 days. The next morning (6:00), all larvae released at the same day from the adult colonies that were collected from the same site condition (control or high- $\mathrm{CO}_{2}$ site) were pooled, and about each 150 larvae released from control or high- $\mathrm{CO}_{2}$ site adults were allocated into plastic container $(750 \mathrm{ml})$ filled with the same control or high- $\mathrm{CO}_{2}$ seawater used for adults. Although we lose the genetical differentiation, larvae released from different colonies were pooled to get enough number of samples for the following measurements. Those larvae that following measurements were conducted the same day the larvae were collected, were designated as the Day 0 sample (2 treatments: larvae released from corals from the control and high- $\mathrm{CO}_{2}$ sites and reared under the same control or high- $\mathrm{CO}_{2}$ seawater conditions, respectively). After collecting larvae for Day 0 , each 150 larvae released from control and high- $\mathrm{CO}_{2}$ sites adults were reciprocated into containers (3-4 containers per treatment according to the released number of larvae) containing either control or high- $\mathrm{CO}_{2}$ seawater and cultured for 5 days, designated as the Day 5 sample ( 4 treatments: larvae released from coral from the control and high- $\mathrm{CO}_{2}$ sites and reared, reciprocally, under both control and high- $\mathrm{CO}_{2}$ seawater conditions, respectively). The same procedure written above was repeated for 6 days using the larvae released from control and high- $\mathrm{CO}_{2}$ sites adults each day. Seawater within the containers was changed every day and seawater temperatures were controlled by keeping the containers within a running seawater bath. The following measurement were conducted for the Day 0 and Day 5 samples, respectively.

\section{Larval Metabolic Activity}

Light photosynthesis and dark respiration rate of the Day 0 and Day 5 larvae samples were measured for all treatments. The symbiotic zooxanthella of pocilloporid corals such as $P$. acuta are known to be transmitted directly from the adult to the larvae (Atoda, 1947). Ten larvae from each treatment were held in airtight $2 \mathrm{ml}$ glass vials containing pre-filtered control or high- $\mathrm{CO}_{2}$ seawater. After 20 min acclimatization, oxygen concentrations were measured with a fiber optic oxygen electrode (FIBOX 3, PreSens) for $5 \mathrm{~min}$ every $30 \mathrm{~min}$ under LED light $(83 \pm 5 \mu \mathrm{mol}$ photon $\mathrm{m}^{-2} \mathrm{~s}^{-1}$ ) or dark conditions. This measurement was conducted for 9-12 replicates consisting of 10 larvae for each of the 2 and 4 treatments at Day 0 and Day 5, respectively.

\section{Larval Zooxanthella Density and Chlorophyll-a Concentration}

To evaluate the density of zooxanthella and chlorophyll- $a$ (Chla) concentration in the larvae, each 10 larvae group used for the photosynthesis and respiration rate measurement were pooled into a $1.5 \mathrm{ml}$ microtube, and homogenized with a microhomogenizer. Thereafter, $150 \mu \mathrm{l}$ of filtered seawater was added, mixed again and $50 \mu \mathrm{l}$ of the homogenized sample was used for counting zooxanthellae numbers by a hemocytometer. The 
remaining $100 \mu \mathrm{l}$ sample was filtered through pre-combusted $\left(450^{\circ} \mathrm{C}, 4 \mathrm{~h}\right) \mathrm{GF} / \mathrm{F}$ glass filters, and Chl- $a$ was extracted within a $\mathrm{N}, \mathrm{N}$-dimethylformamide (DMF) solutions, and measured using a Trilogy fluorometer (Turner Design) following Holm-Hansen et al. (1965) method.

\section{Adult Zooxanthella Density and Chlorophyll-a Concentration}

Since we found differences in the zooxanthella density and Chla concentration in coral larvae from the control and high- $\mathrm{CO}_{2}$ sites, we also evaluated the density of zooxanthella and Chla concentration of adult colonies. A piece of an additional 4 colonies of $P$. acuta were sampled from each site after all the larval experiments were complited. After collection, they were immediately brought to PICRC and the tissue from each coral piece was removed using a waterpik and filtered seawater. After homogenizing the seawater containing the coral tissue, the sample was centrifuged three times and zooxanthellae numbers counted using a hemocytometer. Additionally, a known amount of the sample was filtered through pre-combusted $\left(450^{\circ} \mathrm{C}, 4 \mathrm{~h}\right)$ GF/F glass filters, extracted with DMF and Chl- $a$ measured using the Trilogy fluorometer. The surface area of each piece was measured using the aluminum foil technique (Marsh, 1970) and the zooxanthella density and Chl-a concentration was standardized by surface area.

\section{Larval Dry Weight}

To evaluate the larval dry weight, each 20 larvae from Day 0 and Day 5 samples were collected on pre-combusted and preweighted GF/F glass filters $\left(450^{\circ} \mathrm{C}, 4 \mathrm{~h}\right)$ from each of the 2 and 4 treatments at Day 0 and Day 5, respectively. Filters were frozen at $-80^{\circ} \mathrm{C}$ and then freeze-dried and weighted, and the weight per larvae was calculated. Each filter with 20 larvae were used as a replicate, and the replicate number per treatment was 4 to 13 (see Figure 4 for detail).

\section{Larval Lipid}

To evaluate the lipid content, 50 larvae from Day 0 and Day 5 samples were collected on pre-combusted and pre-weighted GF/F glass filters $\left(450^{\circ} \mathrm{C}, 4 \mathrm{~h}\right)$ for each of the 2 and 4 treatments at Day 0 and Day 5, respectively. Filters were frozen at $-80^{\circ} \mathrm{C}$ until lipid analysis. Each filter with 50 larvae were used as a replicate, and the numbers of filter replications per treatment was 3 to 6 (see Figure 5). All filters were first freeze-dried, weighted and the lipids extracted following Harii et al. (2010). Briefly, lipids were extracted within a 6:4 dichloromethane:methanol solution, and concentrated by removing water with $\mathrm{Na}_{2} \mathrm{SO}_{4}$ and the amount of extracted lipid weighted. The amount of lipid was calculated as the percentage of lipid per larvae by dividing the extracted lipid weight by the dry weight of 50 larvae and the number of larvae.

\section{Adult Experiment}

To evaluate the possibility of any acclimatization or adaptation responses of adult colonies, 10 different colonies of $P$. acuta were collected from the same sites that corals were sampled for larval collection; the high- $\mathrm{CO}_{2}$ site within Nikko Bay and the control site outside the bay in February 2017. All colonies collected were immediately brought to PICRC, and two nubbins of about 5$7 \mathrm{~cm}^{2}$ were taken from each colony and glued to plastic screws. Two days later, the buoyant wet weigh of all 40 P. acuta nubbins were measured with an electronic balance $(0.1 \mathrm{mg}$ precision, HR-200, A\&D, Japan) according to Davies (1989). Thereafter, each 20 nubbins (10 nubbins originated from control and 10 nubbins from high- $\mathrm{CO}_{2}$ sites) were set into a mesh panel (ca. $1 \mathrm{~m}^{2}$ ), and the nubbins were reciprocally transplanted back to each of the high- $\mathrm{CO}_{2}$ and control sites till October 2017. This transplantation period was decided so that the corals experience the two different seasons (dry season: February to May and wet season: July to September) at Palau (Watanabe et al., 2006). Seawater carbon chemistry at each site was measured six times during the transplantation as explained above (Table 2).

After 7 months, all nubbins were re-collected, and brought back to PICRC for photosynthesis rate, dark respiration rate and buoyant wet weight measurements. Additionally, seawater from each site was collected to use for the following photosynthesis and respiration rate measurements. Although most coral nubbins were alive, all of the 10 nubbins that were collected at the control site (outside of Nikko Bay) and transplanted to the high- $\mathrm{CO}_{2}$ site (within Nikko Bay) died, and hence we could not take any measurement for those nubbins.

Photosynthesis and dark respiration were measured in $500 \mathrm{ml}$ air-tight glass chamber with stir bars during the daytime under meta-halide lump (250 $\mu \mathrm{mol}$ photon $\mathrm{m}^{-2} \mathrm{~s}^{-1}$ ), and during the nighttime under dark conditions, respectively. Each glass container was filled with the seawater from the same site the corals were retrieved from and submerged within a water bath to control seawater temperatures. Oxygen concentrations were measured with a fiber optic oxygen electrode (FIBOX 3, PreSens) for $1 \mathrm{~min}$ every $15 \mathrm{~min}$. After photosynthesis and dark respiration measurement, the buoyant wet weight of all nubbins was measured, and calcification rates were calculated based on the change in dry weight measured before transplantation. All photosynthesis, dark respiration and calcification rates were normalized by surface area.

\section{Statistical Analysis}

The larval data measured at Day 0 were analyzed with a student $t$-test between the two sites the parental colonies were collected from (control and high- $\mathrm{CO}_{2}$ sites). When the data did not meet the assumption of normality, data was analyzed with a Wilcoxon rank test. The larval data measured at Day 5 were analyzed by 2-way ANOVA (Type III was used for all unbalanced designed data) with fixed factors of the site that parental colonies were collected from (control and high- $\mathrm{CO}_{2}$ site) and the environment larval were cultured under (control and high$\mathrm{CO}_{2}$ conditions) and their interactions. For the photosynthesis, dark respiration and calcification rates of adult corals, because we could not get data for the nubbins from the control site transplanted to the high- $\mathrm{CO}_{2}$ site, data were analyzed with restricted maximum likelihood (REML) with the 3 treatments (from control-transplanted to control, from $\mathrm{CO}_{2}$-transplanted to $\mathrm{CO}_{2}$, from $\mathrm{CO}_{2}$-transplanted to control) as a fixed factor and colonies as a random effect. Variables with significant interactions 


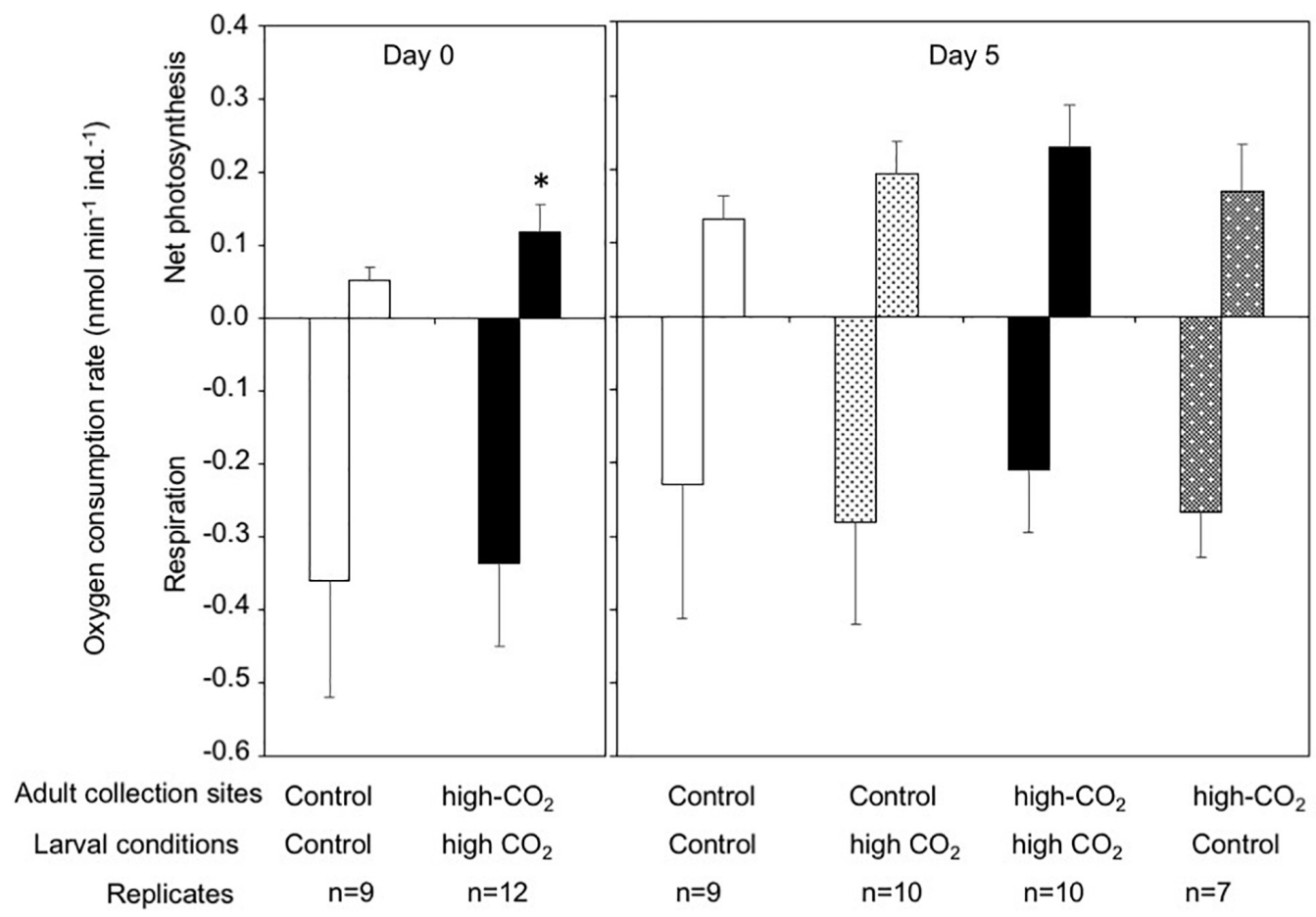

FIGURE 1 | Net photosynthesis and respiration rates of Pocillopora acuta larvae released from adults collected at control (white bar) and high-CO 2 sites (black bar) at Day 0 , and at Day 5 after larvae from the control site were reared under control (white bar) or high $\mathrm{CO}_{2}$ (light gray) $\mathrm{conditions}$, and larvae from high- $\mathrm{CO}_{2}$ site were reared under high $\mathrm{CO}_{2}$ (black bar) or control (dark gray) conditions. At Day 0 , differences among larvae from control and high- $\mathrm{CO}_{2}$ sites were compared by $t$-test, and asterisk shows significant differences. At Day 5, both net photosynthesis and respiration did not show significant differences among larvae originating from control and high $\mathrm{CO}_{2}$ parents, or among larvae cultured under control and high $\mathrm{CO}_{2}$ conditions. The replicate number are shown as $n$ in the graph. Average $\pm \mathrm{SD}$.

were examined further with Tukey's honest significant differences (HSD) test. Assumptions of normality and variables were tested and transformed for analysis when necessary. Statistical analysis was carried out in R (R.2.7.2).

\section{RESULTS}

\section{Larval Experiment}

The larval net photosynthesis rate measured at Day 0 just after released from the adults collected at the high- $\mathrm{CO}_{2}$ site within Nikko Bay was significantly higher than larvae from the control site adults (student $t$-test, $t=-4.7, p=0.0001$, Figure 1). Respiration rates were not significantly different among the two larval groups (student $t$-test, $t=-0.4, p=0.69$ ). After the larvae were reciprocally cultivated at control or high $\mathrm{CO}_{2}$ seawater for 5 days, photosynthesis rate of the larvae cultured at high- $\mathrm{CO}_{2}$ was significantly higher than control seawater regardless of the seawater conditions where they originated from $\left[F_{(1,32)}=8.68, p=0.005\right]$, with no interaction (Figure 1 and Table 3). Respiration rate did not differ based on origin of the parents, or the culture condition, with no interaction between the two factors $\left[F_{(1,32)}=1.65, p=0.20\right.$, Figure 1 and Table 3].

Zooxanthella densities of larvae released from adults originating from the high- $\mathrm{CO}_{2}$ site were significantly higher compared to larvae from control adults at Day 0 ( $t$-test, $t=-3.2$, $p=0.003$, Figure 2). A similar trend was also observed at Day 5, where zooxanthella densities in the larvae originating from high- $\mathrm{CO}_{2}$ adults were significantly higher compared to larvae from control adults, regardless of the seawater conditions they were cultured under $\left[F_{(1,36)}=9.31, p=0.004\right]$, with no interaction $\left[F_{(1,36)}=1.86, p=0.18\right.$, Figure 2 and Table 3]. Chl- $a$ concentrations did not differ among larvae released from adults originating from control and high- $\mathrm{CO}_{2}$ sites at Day 0 (Wilcoxon-rank test, $p=0.09$, Figure 2). However, at Day 5, Chl- $a$ of the larvae originating from high- $\mathrm{CO}_{2}$ adults was significantly higher than control larvae $\left[F_{(1,32)}=59.9\right.$, $p<0.001$ ], with a significant interaction among parent origin and the seawater condition that larvae were cultured under $\left[F_{(1,32)}=10.25, p=0.003\right.$, Table 3$]$. The Chl- $a$ of larvae released from control adults cultured under high- $\mathrm{CO}_{2}$ seawater was significantly lower than the other larvae (Tukey's HSD, Figure 2). In addition to the larvae, both zooxanthella density ( $t$-test, $t=-5.6, p=0.001)$ and Chl- $a$ ( $t$-test, $t=-2.4$, $p=0.05$ ) of adult corals originating from the high- $\mathrm{CO}_{2}$ site were significantly higher than in adults originating from the control site (Figure 3).

The dry weight of the larvae released from control adults was significantly higher than the larvae released from high- $\mathrm{CO}_{2}$ adults at Day 0 (Wilcoxon-rank test, $p=0.02$, Figure 4). However, after 5 days of culture, the dry weight of larvae 


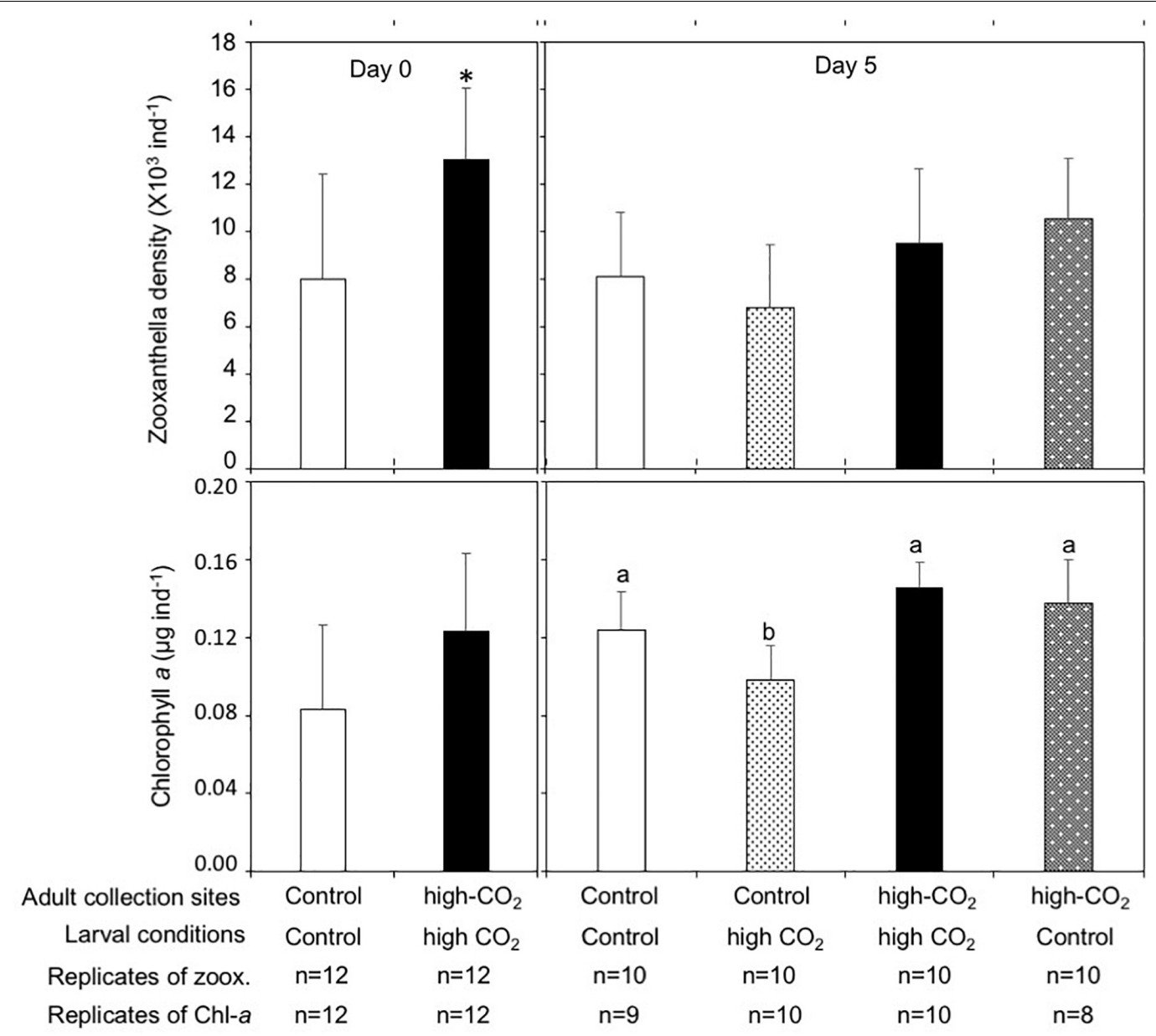

FIGURE 2 | Zooxanthella density and Chl-a concentrations in Pocillopora acuta larvae released from adults collected at control (white bar) and high-CO 2 (black bar) sites at Day 0 , and at Day 5 after being reciprocally reared under control or high $\mathrm{CO}_{2}$ conditions. At Day 0 differences among larvae from control and high- $\mathrm{CO}_{2}$ sites were compared by $t$-test and Wilcoxon-test, respectively. Asterisk shows significant differences among control and high $\mathrm{CO}_{2}$. At Day 5 , both zooxanthella density $\left[F_{(1,36)}=9.31, p=0.004\right]$ and $\mathrm{Chl}-\mathrm{a}\left[F_{(1,36)}=59.9, p<0.001\right]$ of the larvae originating from high $\mathrm{CO}_{2}$ adults were significantly higher compared to larvae originating from control adults. Additionally, Chl-a showed a significant interaction among the parent origin and the seawater condition that larvae were cultured under $\left[F_{(1,32)}=10.2, p=0.003\right.$, Table 3]. Different letters show significant differences among treatment by Tukey's HSD. The replicate number are shown as $n$ in the graph. Average $\pm \mathrm{SD}$.

did not show any significant differences among parent origin $\left[F_{(1,18)}=0.23\right]$ and the seawater condition that larvae were cultured under $\left[F_{(1,18)}=0.95\right.$, Figure 4 and Table 3]. Lipid concentrations in larvae released from control and high- $\mathrm{CO}_{2}$ adults did not show any significant differences at Day 0 ( $t$-test, $t=0.9, p=0.39$, Figure 5). However, after 5 days of culture, the lipid concentration displayed an interaction effect among the origin of adults and the conditions the larvae were cultured under $\left[F_{(1,17)}=7.74\right.$, $p=0.01$, Figure 5 and Table 3]. When the larvae released from adults originating from the control site were cultured under high $\mathrm{CO}_{2}$ seawater, lipid concentrations were significantly lower than when the larvae were cultured under control conditions (Tukey's HSD, Figure 5). Meanwhile, larvae released from adult originating from the high- $\mathrm{CO}_{2}$ site did not show any difference when cultured under control or high$\mathrm{CO}_{2}$ seawater.

\section{Adult Experiment}

While only one nubbin collected at the control site and transplanted to the control site died, all 10 nubbins derived from each 10 different colonies collected at control site and transplanted to the high- $\mathrm{CO}_{2}$ site died after 7 months. No nubbins collected from the high- $\mathrm{CO}_{2}$ site and transplanted to the control or high- $\mathrm{CO}_{2}$ sites died. Calcification rates for the nubbins collected from the high- $\mathrm{CO}_{2}$ site and transplanted to their original high- $\mathrm{CO}_{2}$ site were significantly higher than the nubbins collected from the high- $\mathrm{CO}_{2}$ site and transplanted to the control site [REML, $F_{(2,18.5)}=4.60, p=0.02$, Figure 6]. Additionally, net photosynthesis rates in the nubbins collected from the high- $\mathrm{CO}_{2}$ site and transplanted to their original high$\mathrm{CO}_{2}$ site was significantly higher than the nubbins transplanted to the control site from both the control and high- $\mathrm{CO}_{2}$ site [REML, $F_{(2,19.1)}=13.56, p=0.0002$, Figure 6]. 


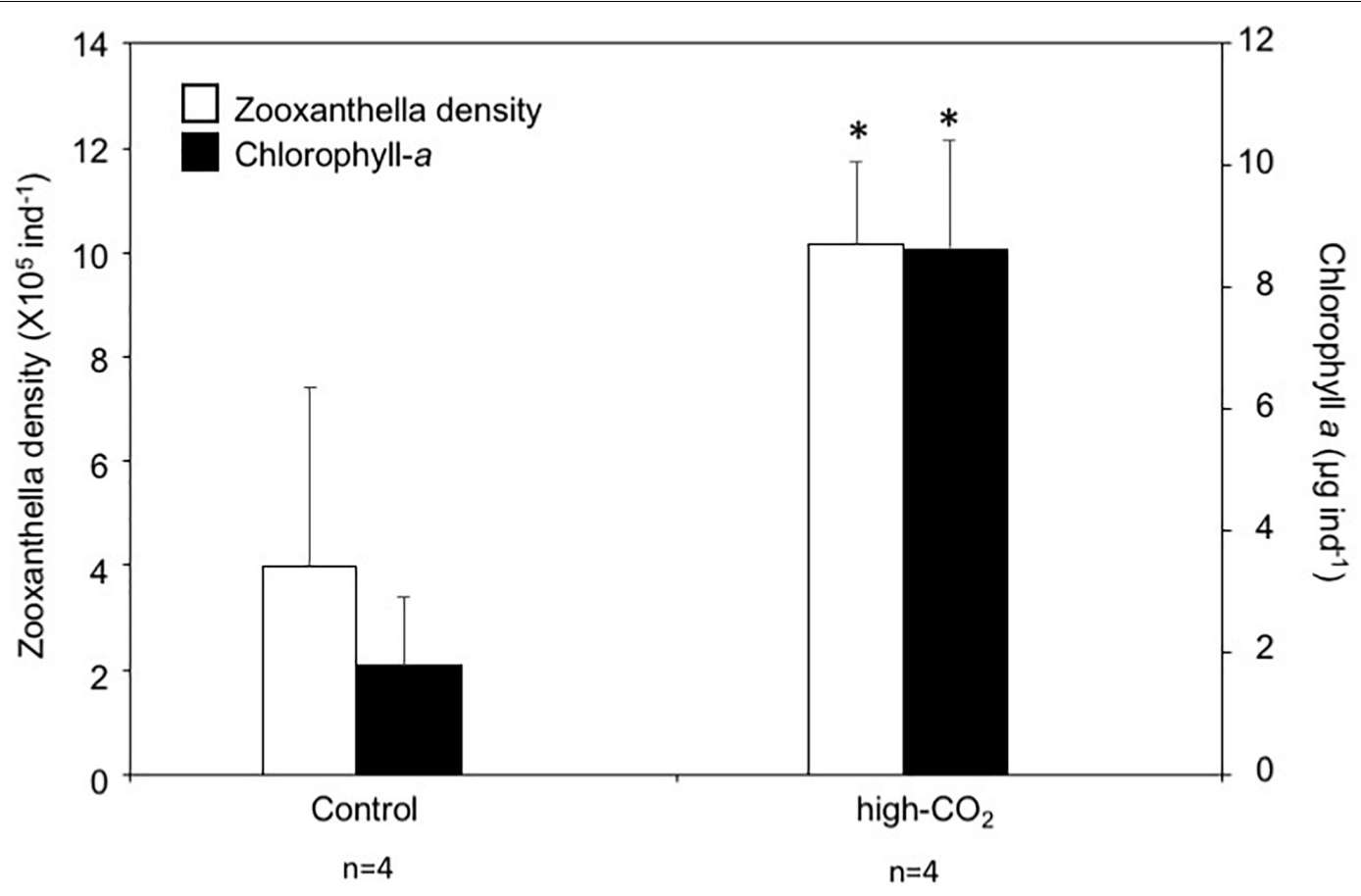

Adult cond.

FIGURE 3 | Zooxanthella density and Chl-a concentration of Pocillopora acuta adults collected at control (white bar) and high-CO 2 (black bar) sites. Asterisks show significant differences among control and high $\mathrm{CO}_{2}$ adults analyzed by $t$-test. The replicate number are shown as $n$ in the graph. Average $\pm \mathrm{SD}$.

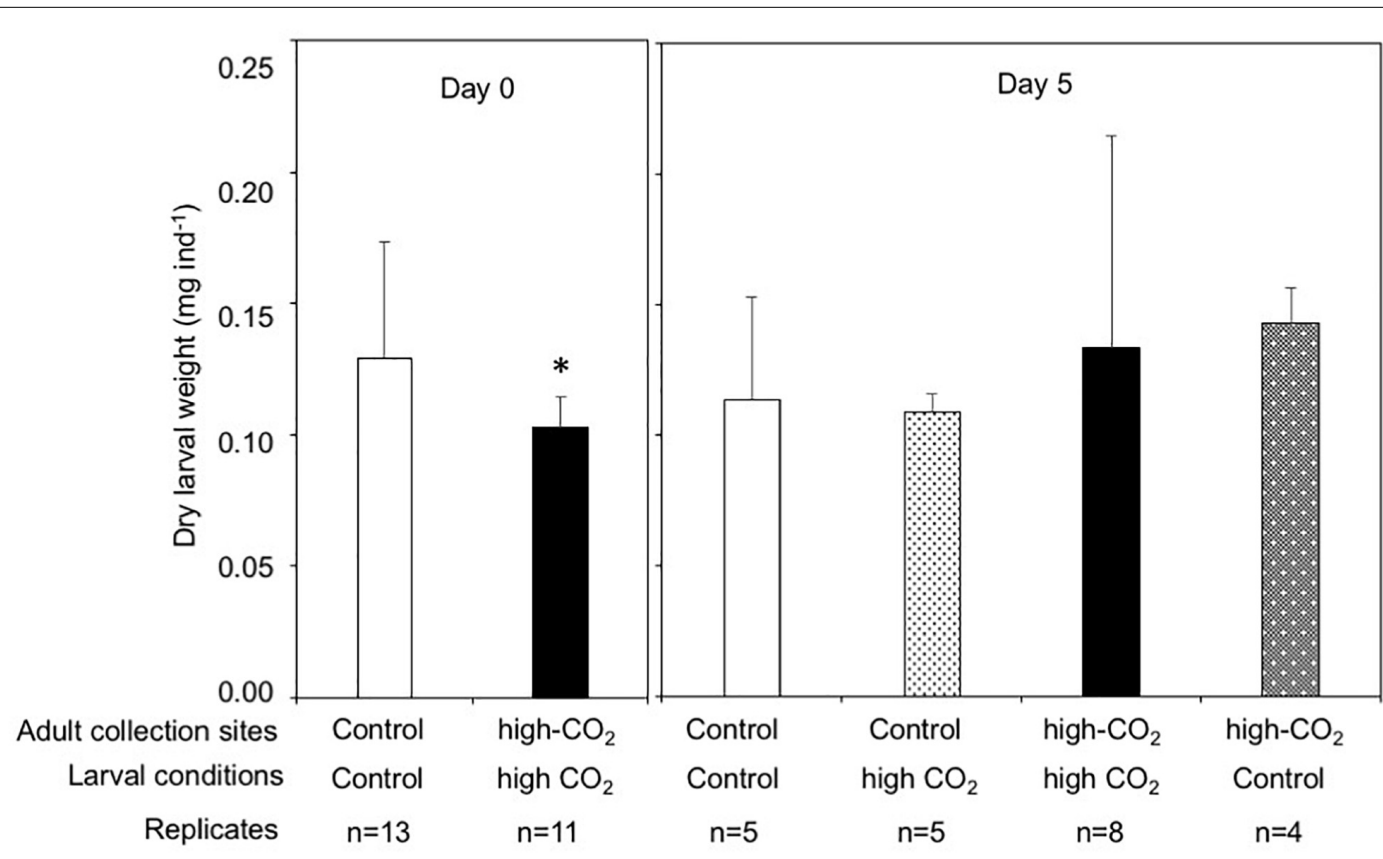

FIGURE 4 | Dry weight of Pocillopora acuta larvae released from adult collected at control (white bar) and high-CO ${ }_{2}$ (black bar) sites at Day 0 , and at Day 5 after being reciprocally reared under control or high $\mathrm{CO}_{2}$ conditions. At Day 0 , differences among larvae from control and high- $\mathrm{CO}_{2}$ sites were compared by Wilcoxon rank test, and asterisk shows significant differences. At Day 5 , dry weight did not show significant differences among larvae originating from control and $\mathrm{CO}_{2}$ parents, or among larvae cultured at control and $\mathrm{CO}_{2}$ conditions. The replicate number are shown as $n$ in the graph. Average $\pm \mathrm{SD}$. 


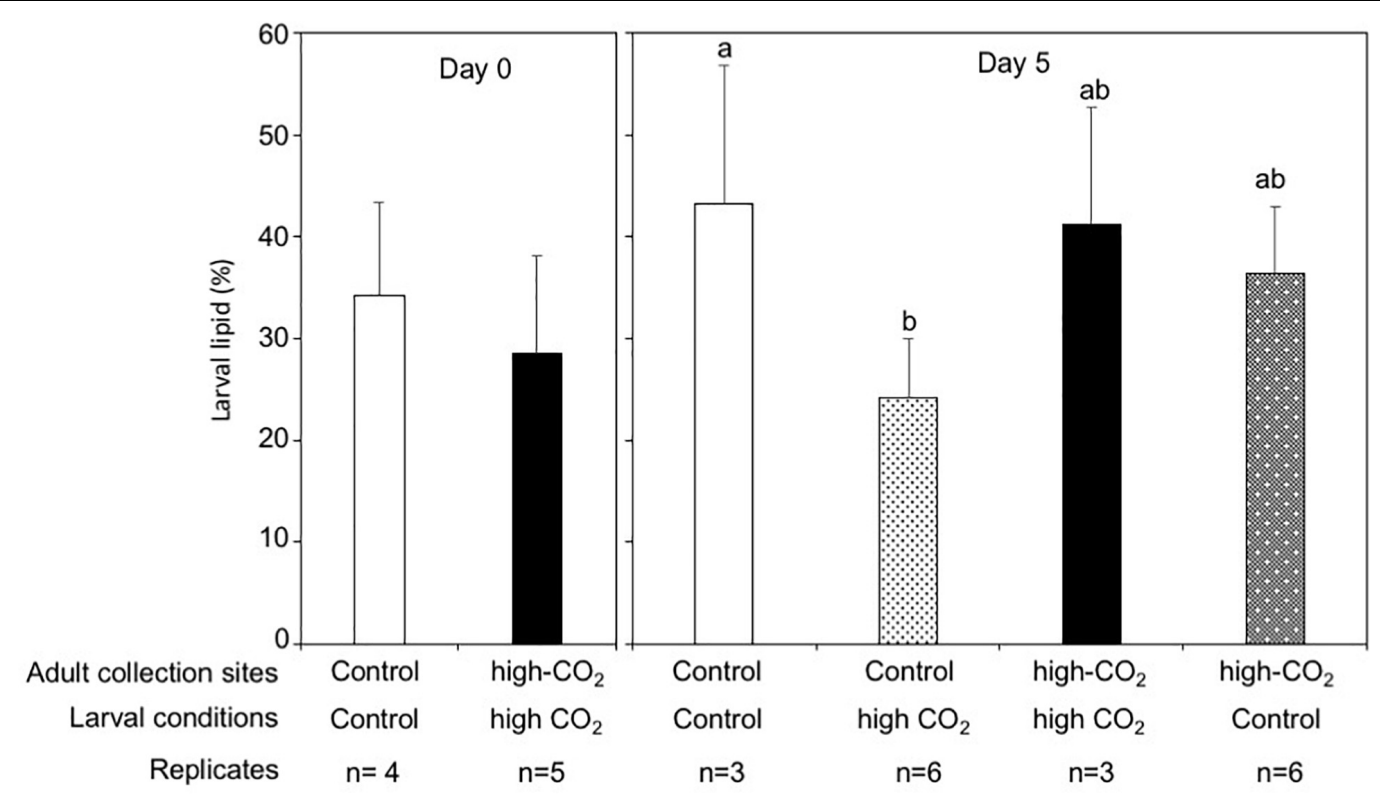

FIGURE 5 | Lipid percentage in Pocillopora acuta larvae released from adults collected at control (white bar) and high-CO 2 site (black bar) sites at Day 0, and at Day 5 after being reciprocally reared under control or high $\mathrm{CO}_{2}$ conditions. At Day 0 , differences among larvae from control and high-CO $\mathrm{O}_{2}$ sites were compared by $t$-test. After 5 days of culture, the lipid concentration display an interaction effect among the origin of adult and the condition of seawater the larvae were cultured under $\left[F_{(1,17)}=7.74, p=0.01\right]$. Different letters show significant differences among treatment by Tukey's HSD. The replicate number are shown as $n$ in the graph. Average $\pm \mathrm{SD}$.

TABLE 2 | Seawater carbon chemistry measured at control and $\mathrm{CO}_{2}$ site at field where the adult corals were reciprocally transplanted for 7 months.

\begin{tabular}{|c|c|c|c|c|c|c|}
\hline & & Temperature & Salinity & pH & pCO2 & $\mathrm{TA}\left(\mu \mathrm{mol} \mathrm{Kg}^{-1}\right)$ \\
\hline \multirow[t]{2}{*}{ Field } & Control site & $29.3 \pm 0.7$ & $33.5 \pm 0.21$ & $8.15 \pm 0.04$ & $430 \pm 53$ & $2206 \pm 23$ \\
\hline & CO2 site & $30.5 \pm 0.6$ & $32.5 \pm 0.26$ & $7.79 \pm 0.05$ & $886 \pm 152$ & $1895 \pm 16$ \\
\hline
\end{tabular}

Those measurement was conducted for five times. Seawater pCO2 was calculated by measured temperature, salinity pH (NBS scale) and total alkalinity (TA). Mean $\pm S D n=6$.

\section{DISCUSSION}

Although tropical coral reefs provide number of ecological functions and economic values, we still lack information on whether long-living corals have the capacity to show acclimatization or adaptation responses to the environmental change (Torda et al., 2017). Here we first found that adult corals and the next-generation larvae which are potentially exposed for multigeneration to naturally acidified environment show higher fitness under their condition similar to their original sites. These results provide, insights for the potential of corals to acclimatize or adapt to the environmental change including $\mathrm{CO}_{2}$ conditions.

The $P$. acuta larvae released from adults originating from the high- $\mathrm{CO}_{2}$ site showed significantly higher photosynthesis rates, which may be due to the higher zooxanthellae density of larvae from the high- $\mathrm{CO}_{2}$ site compared to those from the control site. Since the adult $P$. acuta colonies originating from the high- $\mathrm{CO}_{2}$ site also showed higher zooxanthella density compared to the control site colonies, it appears that the amount of zooxanthella in the parent can affect amount transmitted to larvae, suggesting strong parental effects on next generation. Reasons for adult corals from the high- $\mathrm{CO}_{2}$ site within Nikko Bay showing higher zooxanthellae densities may related to (1) the high seawater $p \mathrm{CO}_{2}$ concentration, which may enhance primary production, (2) the slightly higher nutrient concentrations (Table 1) or (3) the lower light intensity observed within the bay (control site: $336 \pm 341 \mu \mathrm{mol}$ photon $\mathrm{m}^{-2} \mathrm{~s}^{-1}$, high- $\mathrm{CO}_{2}$ site: $71 \pm 95 \mu \mathrm{mol}$ photon $\mathrm{m}^{-2} \mathrm{~s}^{-1}$, Table 1, Supplementary Figure 1). Previous studies demonstrated increased ammonium concentrations induced proliferation of zooxanthella in both adults (Muller-Parker et al., 1994) and larvae of $P$. damicornis (Gaither and Rowan, 2010). In addition, zooxanthella density has been reported to increase under low light intensity by the increase in the zooxanthella division and decrease in zooxanthella degradation, which has been suggested to be an acclimation strategy of corals to low light environment (Falkowski and Dubinsky, 1981; Stimpson, 1997; Titlyanov et al., 1999). Hence all the above factors can be suggested as reasons for the differences observed in the high- $\mathrm{CO}_{2}$ adults. For Chl- $a$, although there was no significant differences among control and high- $\mathrm{CO}_{2}$ larvae at Day 0, after 5 days of culture, the Chl- $a$ was significantly lower in larvae originating from the control site 
TABLE 3 | Two-way ANOVA table for larval experiments.

\begin{tabular}{|c|c|c|c|c|}
\hline & & df & $\boldsymbol{F}$ & $p$ \\
\hline \multirow[t]{4}{*}{ Net Photosynthesis } & Adult & 1 & 2.58 & 0.11 \\
\hline & Larvae & 1 & 8.68 & 0.005 \\
\hline & Adult $\times$ Larvae & 1 & 0.08 & 0.76 \\
\hline & Error & 32 & & \\
\hline \multirow[t]{4}{*}{ Dark Respiration } & Adult & 1 & 1.62 & 0.21 \\
\hline & Larvae & 1 & 0.87 & 0.35 \\
\hline & Adult $\times$ Larvae & 1 & 1.65 & 0.20 \\
\hline & Error & 32 & & \\
\hline \multirow[t]{4}{*}{ Zooxanthella density } & Adult & 1 & 9.31 & 0.004 \\
\hline & Larvae & 1 & 0.71 & 0.4 \\
\hline & Adult×Larvae & 1 & 1.86 & 0.18 \\
\hline & Error & 36 & & \\
\hline \multirow[t]{4}{*}{ Chl-a } & Adult & 1 & 59.9 & $<0.001$ \\
\hline & Larvae & 1 & 1.43 & 0.23 \\
\hline & Adult $\times$ Larvae & 1 & 10.2 & 0.003 \\
\hline & Error & 32 & & \\
\hline \multirow[t]{4}{*}{ Dry weight } & Adult & 1 & 1.50 & 0.23 \\
\hline & Larvae & 1 & 0.003 & 0.95 \\
\hline & Adult $\times$ Larvae & 1 & 0.02 & 0.87 \\
\hline & Error & 18 & & \\
\hline \multirow[t]{4}{*}{ Lipid } & Adult & 1 & 7.94 & 0.01 \\
\hline & Larvae & 1 & 0.61 & 0.44 \\
\hline & Adult $\times$ Larvae & 1 & 7.74 & 0.01 \\
\hline & Error & 17 & & \\
\hline
\end{tabular}

Statistically significant values are shown in bold.

cultured under high- $\mathrm{CO}_{2}$ conditions, while larvae from the high- $\mathrm{CO}_{2}$ site did not show any change between control and high- $\mathrm{CO}_{2}$ conditions. This may suggest that, although larvae from parents living at control corals show some potential stress responses to high $p \mathrm{CO}_{2}$ seawater, larvae from high- $\mathrm{CO}_{2}$ corals are able to tolerate a wide range of $p \mathrm{CO}_{2}$ concentration.

The dry weight of the larvae released from the adults originating from the high- $\mathrm{CO}_{2}$ site was lower compared to larvae from the control site at the Day 0 , suggesting that they were smaller in size or of lower density. Interestingly, the same trend in the production of smaller larval size was observed when the adult of $P$. damicornis adult were culture under high $\mathrm{CO}_{2}$ and high temperatures for 1.5 months (Putnam and Gates, 2015). Here we measured the dry weight instead of larval size because we found it difficult to measure the swimming larval size correctly, but we expect that the larval dry weight correlates well with their volume. The production of smaller larvae has been suggested to be a potential adaptive plasticity of adults under predictable stressful conditions (Crean and Marshall, 2009; Putnam and Gates, 2015), which can also be the case observed in this study. However, here we did not observe any potential stress responses such as declines of physiological performance in either larvae or adult corals from the high- $\mathrm{CO}_{2}$ site. Additionally, after 5 days of culture, the dry weight of larvae from all conditions did not show any significant differences, suggesting that the initially low dry weight may not negatively affect the subsequent development of the larvae from the high- $\mathrm{CO}_{2}$ site. Interestingly, although we were not able to prove statistically because we did not count the number of larvae released per colony, we observed that the summed number of larvae released by the 5 colonies from the high- $\mathrm{CO}_{2}$ site was larger (total of 1383 larvae from 5 colonies) compared to the control site (total of 875 larvae from 5 colonies, Figure 7A). Additionally, same trend was also found for the corals collected on September 2017 (those larvae were not used for the present study) from the same high- $\mathrm{CO}_{2}$ site (total of 1262 larvae from 5 colonies) compared to the control site (total of 919 larvae from 5 colonies, Figure 7B). Although further studies should be conducted before make any firm conclusion, this may suggest that corals from the high$\mathrm{CO}_{2}$ site tend to release a larger number of larvae of smaller size compared to the corals at control site, which can be a potential adaptation strategy of the corals living within this high- $\mathrm{CO}_{2}$ Nikko bay.

Another difference that was found among larvae from the control and high- $\mathrm{CO}_{2}$ sites was that the larvae from control site cultured under high- $\mathrm{CO}_{2}$ conditions for 5 days shows significantly lower lipid percentage. Larvae from the high- $\mathrm{CO}_{2}$ site did not show any differences in lipids among control and high $\mathrm{CO}_{2}$ conditions. Several studies have indicated that corals may need further energy to compensate for their internal $\mathrm{pH}$ when reared under low pH (Cohen and Holocomb, 2009; Allemand et al., 2011; Edmunds, 2011), so excess use of lipid could be expected in larvae from the control site reared under high $\mathrm{CO}_{2}$. Meanwhile, larvae from the parents originating from the high$\mathrm{CO}_{2}$ site seems to be acclimatized or adapted to the high- $\mathrm{CO}_{2}$ seawater. Larval lipid content has also been suggested to be used as energy for locomotion and mucus secretion (Richmond, 1987; Gaither and Rowan, 2010). Although we did not observe any clear differences in larval locomotion, effects of $\mathrm{CO}_{2}$ on these biological activities can also be expected (Bergman et al., 2018). In any case, since the lipid content of larvae has been proposed as an important factor affecting the duration of the larval period (Harii et al., 2007), and larvae with larger amounts of lipid may benefit post-settlement by growing faster (Richmond, 1987), larvae from the high- $\mathrm{CO}_{2}$ site within Nikko Bay are likely to be conferred an advantage compared to larvae from the control site when under high- $\mathrm{CO}_{2}$ conditions.

In addition to larval responses, reciprocal transplantation of adult corals showed that while all corals originated from Nikko Bay survived when transplanted to either control or high- $\mathrm{CO}_{2}$ sites at Nikko Bay, $P$. acuta colonies originated from the control site were not able to survive within the bay, suggesting the existence of strong selection within the bay. Though, here we need to take into account the fact that all transplanted corals originated outside and inside the bay were put together at same mesh, there might have other interactive effects that influenced their survival. But, because only the out-side corals transplanted within the bay died, even though the corals originated from out-side and in-side the bay were put randomly at the same mesh, it seem that is more likely that the coral mortality rate was influenced by their origin rather than by the mesh. Additionally, considering the fact that corals within the bay showed higher fitness of 


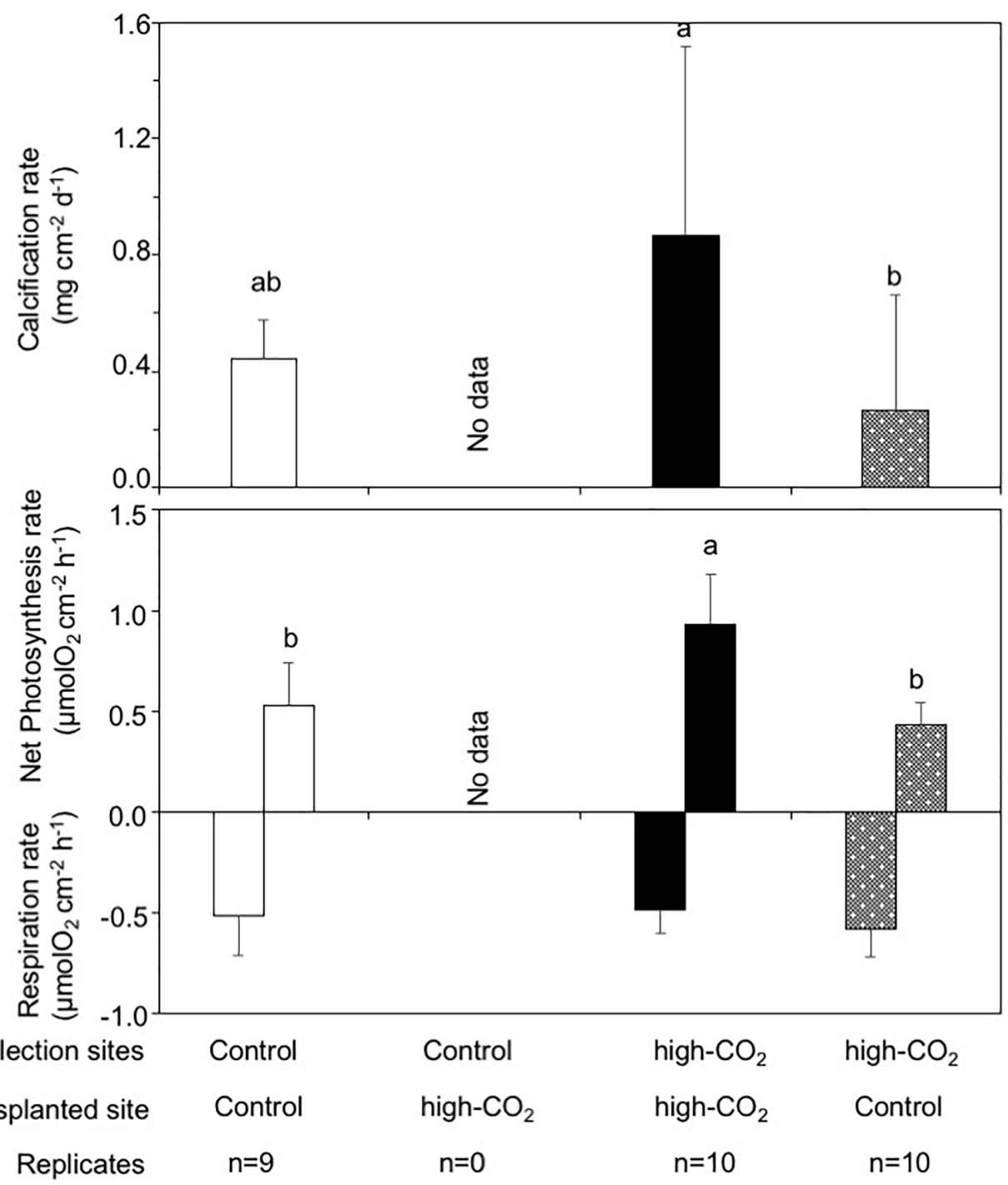

FIGURE 6 | Calcification, net photosynthesis, and respiration of adult corals collected from control and high-CO $\mathrm{CO}_{2}$ sites and reciprocally transplanted to control or high- $\mathrm{CO}_{2}$ site for 7 months. All coral nubbins that were collected from the control site and transplanted to high- $\mathrm{CO}_{2}$ site died after 7 months. Adult corals collected from the high- $\mathrm{CO}_{2}$ site and transplanted to their original high- $\mathrm{CO}_{2}$ site shows significantly higher calcification, net photosynthesis and respiration rates, which are shown by different letters. The replicate number are shown as $n$ in the graph. Average \pm SD.

high calcification and net photosynthesis rates when exposed to the condition they originated from compared to the control condition, it can be suggested that P. acuta living in Nikko Bay are well adapted to the conditions found within the bay. Although we also need to note that not only seawater $p \mathrm{CO}_{2}$ concentration but also several other conditions, such as light intensity, temperature and nutrient concentrations, all differ between the control site and the high- $\mathrm{CO}_{2}$ site (Table 1). Of particular note, light intensity within the bay was less than half that compared to the control site (Supplementary Figure 1), which is mainly due to the higher turbidity (control site: $0.3 \pm 0.15$ FTU, $\mathrm{CO}_{2}$ site: $1.8 \pm 0.8$ FTU). Additionally, seawater temperatures were about $1^{\circ} \mathrm{C}$ higher within the bay (Supplementary Figure 1). Some previous studies indicated that Pocilloporidae corals may have a higher tolerance to high $p \mathrm{CO}_{2}$ condition compared to other corals such as the Acroporidae (Putnam et al., 2013; Comeau et al., 2014). Hence the low survival of $P$. acuta corals from the control site transplanted into the Nikko Bay may be a response to the synergistic impacts of a range of conditions: high $p \mathrm{CO}_{2}$, high temperature, and low light. Although we cannot evaluate the genetic mechanisms as here we lack of molecular approaches, Vidal-Dupiol et al. (2013) revealed that several genes related to calcification, heterotrophy and autotrophy were up-regulated in $P$. damicornis adults reared under low $\mathrm{pH}$ conditions. Epigenetic phenotypic plasticity to high $\mathrm{pCO}_{2}$ by DNA methylation has also been found in the coral P. damicornis (Putnam et al., 2016) and Stylophora pistillata (Liew et al., 2018). Additionally, the 


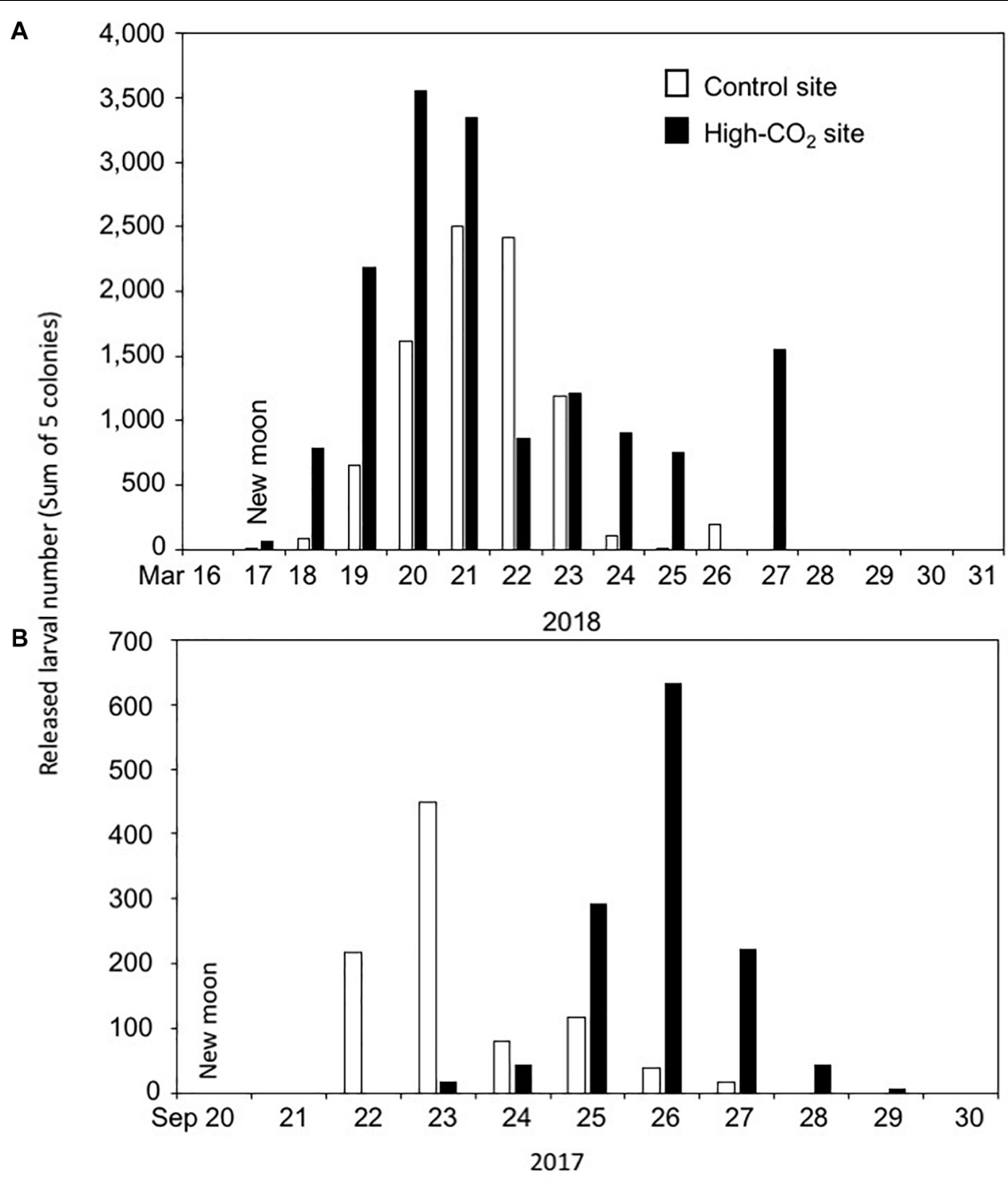

FIGURE 7 | Larval number released each day from the adult corals collected from control and high-CO 2 sites on 2018 (A) and 2017 (B). Larval number are the sum of 5 colonies collected from each site. Larvae start to be released around the null moon.

change in expression of several genes in P. damicornis larvae reared under $\mathrm{OA}$ and high temperature conditions has also been reported (Rivest et al., 2018). Future studies evaluating the potential interactive effects of other environmental factors and the potential genetical differences in corals within the bay are needed for better understanding the mechanisms driving their tolerances.

Although there are several uncertainties, the seawater environmental condition found within Nikko bay has been suggested to be maintained for at least 5000 years (Golbuu et al., 2016). This time period could be long enough for selecting individuals that shows higher fitness to the environmental conditions found within the bay which may have been amplified by the trans-generation acclimatization responses. Additionally, gradual change of the environmental condition including seawater $p \mathrm{CO}_{2}$ found from outside toward the bay (Kurihara et al., unpublished data) may allow the step by step acclimatization of corals to the environment found within the bay. Long-living and high dispersal capacity corals have been suggested to have less capacity of transgenerational epigenetic inheritance to effect rapid phenotypic change to the environmental change (Torda et al., 2017), however, this is one of the first results that indicate the possibility that corals could show local adaptation to high $\mathrm{CO}_{2}$ and other conditions including high temperature and high turbidity. Though, interpretation of these results should take into account the fact that future $\mathrm{OA}$ is expected to occur at whole ocean and at the speed of few decades, the present study gives strong insight for the ability of corals to acclimatize or adapt to different environmental conditions. Future studies evaluating the genetical background of those corals within this bay may give important insights for the potential conservation strategies such as assisted evolution (van Oppen et al., 2017) and understanding the mechanism of organisms to acclimatize and adapt to different environmental conditions, including high $p \mathrm{CO}_{2}$ seawater concentration. 


\section{DATA AVAILABILITY STATEMENT}

The raw data supporting the conclusions of this article will be made available by the authors, without undue reservation.

\section{AUTHOR CONTRIBUTIONS}

HK designed the study, wrote the draft of the manuscript, and performed the statistical analysis. YS mainly performed the larval experiments. HK and IM performed the adult experiments. All authors contributed to manuscript revision, read, and approved the submitted version.

\section{FUNDING}

This work was supported by funding from the Japan Society for the Promotion of Science (JSPS) KAKENHI, grant number:

\section{REFERENCES}

Albright, R., and Mason, B. (2013). Projected near-future levels of temperature and pCO2 reduce coral fertilization success. PLoS One 8:e56468. doi: 10.1371/ journal.pone. 0056468

Allemand, D., Tambutté, E., Zoccola, D., and Tambutté, S. (2011). "Coral calcification, cells to reefs," in Coral Reef: An Ecosystem in Transition, eds Z. Dubinsky and N. Stambler (New York: Springer), 119-150. doi: 10.1007/97894-007-0114-4_9

Atoda, K. (1947). The larval and postlarval development of some reef-building corals, Stylophora pistillata (Esper). Sci. Rep. Tohoku Univ. Ser. 4, 48-64.

Bergman, J. L., Harii, S., Kurihara, H., and Edmunds, P. J. (2018). Behavior of brooded coral larvae in response to elevated pCO2. Font. Mar. Sci. 5:51.

Calosi, P., Rastrick, S. P. S., Lombardi, C., de Guzman, H. J., Davidson, L., Jahnke, M., et al. (2013). Adaptation and acclimatization to ocean acidification in marine ectotherms: an in situ transplant experiment with polychaetes at a shallow CO2 vent system. Philos. Trans. R. Soc. Lond. B. Biol. Sci. 368:20120444. doi: 10.1098/rstb.2012.0444

Chan, N. C. S., and Connolly, S. R. (2013). Sensitivity of coral calcification to ocean acidification: a meta-analysis. Glob. Change Biol. 19, 282-290. doi: 10.1111/gcb. 12011

Cohen, A., and Holocomb, M. (2009). Why corals care about ocean acidification: uncovering the mechanism. Oceanography 22, 118-127. doi: 10.5670/oceanog. 2009.102

Comeau, S., Edmunds, N. B., Spindel, N. B., and Carpenter, R. C. (2014). Fast coral reef calcifiers are more sensitive to ocean acidification in short-term laboratory incubations. Limnol. Oceanogr. 59, 1081-1091. doi: 10.4319/lo.2014.59.3. 1081

Crean, A., and Marshall, D. J. (2009). Coping with environmental uncertainty: dynamic bet hedging as a maternal effect. Philos. Trans. R. Soc. B 364, 10871096. doi: $10.1098 /$ rstb.2008.0237

Davies, P. S. (1989). Short-term growth measurements of coral using an accurate buoyant weighing technique. Mar. Biol. 101, 389-395. doi: 10.1007/bf00428135

Doropoulos, C., Ward, S., Diaz-Pulido, G., Hoegh-Guldburg, O., and Mumby, P. J. (2012). Ocean acidification reduces coral recruitment by disrupting intimate larval-algal settlement interactions. Ecol. Lett. 15, 338-346. doi: 10.1111/j.14610248.2012.01743.x

Edmunds, P. J. (2011). Zooplanktivory ameliorates the effects of ocean acidification on the reef coral Porites spp. Limnol. Oceanogr. 23, 2402-2410. doi: 10.4319/lo. 2011.56.6.2402

Fabricius, K. E., Langdon, C., Uthicke, S., Humphrey, C., Noonan, S., De'ath, G., et al. (2011). Losers and winners in coral reefs acclimatized to elevated
16H05772, Japan International Cooperation Agency (JICA)Japan Science and Technology (JST) SATREPS Program, Uruma funding, and Okinawa Research Core for High Innovative Discipline Science Project from the University of the Ryukyus.

\section{ACKNOWLEDGMENTS}

We are grateful to all the staff of Palau International Coral Reef Center for their support. We thank Dr. Chuki Hongo for assistances at field works and Dr. Saki Harii for the assistance of lipid measurement.

\section{SUPPLEMENTARY MATERIAL}

The Supplementary Material for this article can be found online at: https://www.frontiersin.org/articles/10.3389/fmars. 2020.581160/full\#supplementary-material

carbon dioxide concentrations. Nat. Clim. Change 1, 165-169. doi: 10.1038/ nclimate1122

Falkowski, P. G., and Dubinsky, Z. (1981). Light-shade adaptation of Stylophora pistillata, a hermatypic coral from the Gulf of Eilat. Nature 289, 172-174. doi: 10.1038/289172a0

Gaither, M. R., and Rowan, R. (2010). Zooxanthellar symbiosis in planula larvae of the coral Pocillopora damicornis. J. Exp. Mar. Biol. Ecol. 386, 45-53. doi: 10.1016/j.jembe.2010.02.003

Golbuu, Y., Gouezo, M., Kurihara, H., Rehm, L., and Wolanski, E. (2016). Longterm isolation and local adaptation in Palau's Nikko Bay help corals thrive in acidic waters. Coral Reefs 35, 909-918. doi: 10.1007/s00338-016-1457-5

Hall-Spencer, J. M., Rodolfo-Metalpa, R., Martin, S., Ransome, E., Fine, M., Turner, S. M., et al. (2008). Volcanic carbon dioxide vents show ecosystem effects of ocean acidification. Nature 454, 96-99. doi: 10.1038/nature07051

Harii, S., Nadaoka, K., Yamamoto, M., and Iwao, K. (2007). Temporal changes in settlement, lipid content and lipid composition of larvae of the spawning hermatypic coral Acropora tenuis. Mar. Ecol. Prog. Ser. 346, 89-96. doi: 10. 3354/meps07114

Harii, S., Yamamoto, M., and Hoegh-Guldberg, O. (2010). The relative contribution of dinoflagellate photosynthesis and stored lipids to the survivorship of symbiotic larvae of the reef-building corals. Mar. Biol. 156, 1215-1224. doi: 10.1007/s00227-010-1401-0

Harvey, B. P., McKeown, N. J., Rastrick, S. P. S., Betoloni, C., Foggo, A., Graham, H., et al. (2016). Individual and population-level responses to ocean acidification. Sci. Rep. 6:20194.

Hoegh-Guldberg, O., Mumby, P. J., Hooten, A. J., Steneck, R. S., Greenfield, P., Gomez, E., et al. (2007). Coral reefs under rapid climate change and ocean acidification. Science 318, 1737-1742.

Holm-Hansen, O., Lorenzen, C. J., Holmes, R. W., and Strickland, J. D. H. (1965). Fluorometric determination of chlorophyll. J. Cos. Perm. Int. Explor. Mer. 30, 3-15. doi: 10.1093/icesjms/30.1.3

Inoue, S., Kayanne, H., Yamamoto, S., and Kurihara, H. (2013). Spatial community shift from hard to soft corals in acidified water. Nat. Clim. Change 3, 683-687. doi: $10.1038 /$ nclimate 1855

IPCC (2014). "Climate change 2014: synthesis report," in Proceedings of the Contribution of Working Group I, II and III to the Fifth Assessment Report of the Intergovermental Panel on Climate Change, (Geneva: IPCC).

Isomura, N., and Nishihira, M. (2001). Size variation of planulae and its effect on the lifetime of planulae in three pocilloporid corals. Coral Reefs 20, 309-315. doi: $10.1007 / \mathrm{s} 003380100180$

Kelly, M. W., and Hofmann, G. E. (2012). Adaptation and the physiology of ocean acidification. Funct. Ecol. 27, 980-990. doi: 10.1111/j.1365-2435.2012.02061.x 
Kleypas, J. A., Feely, R. A., Fabry, V. J., Langdon, C., Sabine, C. L., and Robbins, L. L. (2005). Impacts of Ocean Acidification on Coral Reefs and Other Marine Calcifiers: A Guide for Future Research, Report of a Workshop Held 18-20 April 2005. St. Petersburg, FL: NSF, NOAA, and the U.S. Geological Survey.

Kopp, C., Domart-Coulon, I., Barthelemy, D., and Meibom, A. (2016). Nutritional input from dinoflagellate symbionts in reef-building corals is minimal during planula larval stage. Sci. Adv. 2:e1500681. doi: 10.1126/sciadv.1500681

Kroeker, K. J., Kordas, R. L., Crim, R. N., and Singh, G. G. (2010). Meta-analysis reveals negative yet variable effects of oean acidification on marine organisms. Ecol. Lett. 12, 1419-1434. doi: 10.1111/j.1461-0248.2010.01518.x

Lamare, M. D., Liddy, M., and Uthicke, S. (2016). In situ developmental responses of tropical sea urchin larvae to ocean acidification conditions at naturally elevated pCO2 vent sites. Proc. R. Soc. B 283:20161506. doi: 10.1098/rspb.2016. 1506

Lewis, E., and Wallace, D. (1998). "Program developed for $\mathrm{CO}_{2}$ system calculations," in ORNL/CDIAC-105 Carbon Dioxide Information Analysis Center, Oak Ridge National Laboratory (Oak Ridge, TX: U.S. Department of Energy).

Liew, Y. J., Zoccola, D., Li, Y., Tambutté, E., Venn, A. A., Michell, C. T., et al. (2018). Epigenome-associated phenotypic acclimatization to ocean acidification in a reef-building coral. Sci. Adv. 6:eaar8028. doi: 10.1126/sciadv.aar8028

Lohbeck, K. T., Riebesell, U., and Reusch, T. B. H. (2012). Adaptive evolution of a key phytoplankton species to ocean acidification. Nat. Geosci. 5, 346-351. doi: 10.1038/ngeo1441

Marsh, J. A. (1970). Primary productivity of reef-building calcacerous red algae. Ecology 51, 255-263. doi: 10.2307/1933661

McCulloch, M., Falter, J., Trotter, J., and Montagna, P. (2012). Coral resilience to ocean acidification and global warming through $\mathrm{pH}$ up-regulation. Nat. Clim. Change 2, 623-627. doi: 10.1038/nclimate1473

Miller, G. M., Watson, S.-A., Donelson, J. M., McCormick, M. I., and Munday, P. L. (2012). Parental environment mediates impacts of increased carbon dioxide on a coral reef fish. Nat. Clim. Change 2, 858-861. doi: 10.1038/nclimate1599

Muller-Parker, G., McCloskey, L. R., Hoegh-Gulberg, O., and McAuley, P. J. (1994). Effect of ammonium enrichment on animal and algal biomass of the coral Pocillopora damicornis. Pac. Sci. 48, 273-283.

Munday, P. L. (2014). Transgeneration acclimation of fishes to climate change and ocean acidification. F1000Prime Rep. 6:MC4229724.

Nakamura, M., Ohki, S., Suzuki, A., and Sakai, K. (2011). Coral larvae under ocean acidification: survival, metabolism, and metamorphosis. PLoS One 6:e14521. doi: 10.1371/journal.pone.0014521

Nishikawa, A., Katoh, M., and Sakai, K. (2003). Larval settlement rates and gene flow of broadcast spawning (Acropora tenuis) and planula-brooding (Stylophora pistillata) corals. Mar. Ecol. Prog. Ser. 256, 87-97. doi: 10.3354/ meps 256087

Pandolfi, J. M., Connolly, S. R., Marshall, D. J., and Cohen, A. L. (2011). Projecting coral reef future under warming and ocean acidification. Science 333, 418-422. doi: 10.1126/science.1204794

Putnam, H. M., Davidson, J. M., and Gates, R. D. (2016). Ocean acidification influences host DNA methylation and phenotypic plasticity in environmentally susceptible corals. Evol. Appl. 9, 1165-1178. doi: 10.1111/eva.12408

Putnam, H. M., and Gates, R. D. (2015). Preconditioning the reef-building coral Pocillopora damicornis and the potential for trans-generational acclimatization in coral larvae under future climate change conditions. J. Exp. Biol. 218, 2365-2372. doi: 10.1242/jeb.123018

Putnam, H. M., Mayfield, A. B., Fan, T. Y., Chen, C. S., and Gates, R. D. (2013). The physiological and molecular responses of larvae from the reef-building coral Pocillopora damicornis exposed to near-future increases in temperature and pCO2. Mar. Biol. 160, 2157-2173. doi: 10.1007/s00227-012-2129-9

Richmond, R. H. (1987). Energetics, competency, and long-distance dispersal of planulae larvae of the coral Pocillopora damicornis. Mar. Biol. 93, 527-533. doi: $10.1007 /$ bf00392790

Rivest, E. B., Kelly, M. W., DeBiasse, M. B., and Hofmann, G. E. (2018). Host and symbionts in Pocillopora damicornis larvae display different transcriptomic responses to ocean acidification and warming. Front. Mar. Sci. 5:186. doi: 10. 3389/fmars.2018.00186

Schmidt-Roach, S., Lundgren, P., Miller, K. J., Gerlach, G., Noreen, A. M. E., and Andreakis, N. (2013). Assessing hidden species diversity in the coral Pocillopora darmicornis from Eastern Australia. Coral Reefs 32, 161-172. doi: 10.1007/ s00338-012-0959-z

Shamberger, K. E. F., Cohen, A. L., Golbuu, Y., McCorkle, D. C., Lentz, S. J., and Barley, H. C. (2014). Diverse coral communities in naturally acidified waters of a Western Pacific reef. Geophys. Res. Lett. 41, 499-504. doi: 10.1002/ $2013 \mathrm{gl058489}$

Soliman, T., Fernandez-Silva, I., Kise, H., Kurihara, H., and Reimer, J. D. (2019). Population differentiation across small distances in a coral reef-associated vermetid (Ceraesignum maximum) in Palau. Coral Reefs 38, 1159-1172. doi: 10.1007/s00338-019-01849-x

Stimpson, J. (1997). The annual cycle of density of zooxanthellae in the tissues of field and laboratory-held Pocillopora damicornis (Linnaeus). J. Exp. Mar. Biol. Ecol. 214, 35-48. doi: 10.1016/s0022-0981(96)02753-0

Sunday, J. M., Calosi, P., Dupont, S., Munday, P. L., Stillman, J. H., and Reusch, T. B. H. (2014). Evolution in an acidifying ocean. Trends Ecol. Evol. 29, 117-125. doi: 10.1016/j.tree.2013.11.001

Sunday, J. M., Crim, R. N., Harley, C. D. G., and Hart, M. W. (2011). Quantifying rates of evolutionary adaptation in response to ocean acidification. PLoS One 6:e22881. doi: 10.1371/journal.pone.0022881

Thomsen, J., Stapp, L. S., Haynert, K., Schade, H., Danelli, M., Lannig, G., et al. (2017). Naturally acidified habitat selects for ocean acidified-tolerant mussels. Sci. Adv. 3:e1602411. doi: 10.1126/sciadv.1602411

Titlyanov, E. A., Titlyanova, T. V., Tsukahara, J., Van Woesik, R., and Yamazato, K. (1999). Experimental increases of zooxanthellae density in the coral Stylophora pistillata elucidate adaptive mechanisms for zooxanthellae regulation. Symbiosis 26, 347-362.

Torda, G., Donelson, J. M., Aranda, M., Barshis, D. J., Bay, L., Berumen, M. L., et al. (2017). Rapid adaptive responses to climate change in corals. Nat. Clim. Change 7, 627-636. doi: 10.1038/nclimate3374

van Oppen, M. J. H., Gates, R. D., Blackall, L. L., Cantin, N., Chakravarti, L. J., Chan, W. Y., et al. (2017). Shifting paradigms in restoration of the world's coral reefs. Glob. Change Biol. 23, 3437-3448.

Vargas, C. A., Lagos, N. A., Lardies, M. A., Duarte, C., Manríquez, P. H., Anguilera, V. M., et al. (2017). Species-specific responses to ocean acidification should account for local adaptation and adaptive plasticity. Nat. Ecol. Evol. 1:0084.

Vidal-Dupiol, J., Zoccola, D., Tambutté, E., Grunau, C., Cosseau, C., Smith, K. M., et al. (2013). Genes related to ion-transport and energy production are upregulated in response to $\mathrm{CO} 2$-driven $\mathrm{pH}$ decrease in corals: new insights from transcriptome analysis. PLoS One 8:e58652. doi: 10.1371/journal.pone.00 58652

Watanabe, A., Kayanne, H., Hata, H., Kudo, S., Nozaki, K., Kato, K., et al. (2006). Analysis of the seawater CO2 system in the barrier reef-lagoon system of Palau using total alkalinity-dissolved inorganic carbon diagrams. Limnol. Oceanogr. 51, 1614-1628. doi: 10.4319/lo.2006.51.4.1614

Welch, M. J., and Munday, P. L. (2017). Heritability of behavioural tolerance to high $\mathrm{CO} 2$ in a coral reef fish is masked by nonadaptive phenotypic plasticity. Evol. Appl. 10, 682-693. doi: 10.1111/eva.12483

Conflict of Interest: The authors declare that the research was conducted in the absence of any commercial or financial relationships that could be construed as a potential conflict of interest.

Copyright (c) 2020 Kurihara, Suhara, Mimura and Golbuu. This is an open-access article distributed under the terms of the Creative Commons Attribution License (CC BY). The use, distribution or reproduction in other forums is permitted, provided the original author(s) and the copyright owner(s) are credited and that the original publication in this journal is cited, in accordance with accepted academic practice. No use, distribution or reproduction is permitted which does not comply with these terms. 